ESJ Humanities

\title{
Role of Military From Counter Insurgency to Peace Building: Paradigm Shift in the Sri Lankan Nation-State's Security
}

\author{
D.G. Rajitha Nilaksha Rukshan
}

B.A. (Peradeniya), M.A. (Kelaniya)

Doi: $10.19044 /$ esj.2021.v17n2p99

Submitted: 22 December 2020

Accepted: 11 January 2021

Published: 31 January 2021
Copyright 2021 Author(s)

Under Creative Commons BY-NC-ND

4.0 OPEN ACCESS

Cite As:

Rukshan N.R. (2021). Role of Military From Counter Insurgency to Peace Building: Paradigm Shift in the Sri Lankan Nation-State's Security. European Scientific Journal, ESJ, 17(2), 99. https://doi.org/10.19044/esj.2021.v17n2p99

\section{Abstract}

Historically, Sri Lanka (Ceylon) used to be considered as one of the more stable and secure countries in the South Asian region. In the years after independence it gradually dawned on the government that maintaining national security was a crucial and most challenging contemporary issue faced by the country. At the global level, the role of the Military was understood as being vital for ensuring the safety, security and dignity of the nation-state. And, when national security is threatened on any ground, the military is expected to play a key role in safeguarding it. However, after the military victory was won by defeating the Liberation Tigers of Tamil Eelam (LTTE) in Sri Lanka in 2009 it was expected that a deep sense of peace and tranquility would be restored in the country. Contrary to this expectation, Sri Lankan national security was breached very badly, leadimg to an unstable situation as a result of a series of bomb blasts set off by certain extremist elements on the 21st of April 2019. In this backdrop, it would be a timely exercise to explore and analyze the Sri Lankan nation state's security, peace building initiatives, and the role of the military. Taking this a step further, this study sought to analyze the role played by the military in the post-conflict peace building process as well. The study used qualitative methodology to conduct the investigation. Secondary data sources including books, articles and official reports were utilized to collect information for this study. This research found that in Sri Lanka the military was actively engaged in maintaining national security by using its soft and hard power as appropriate. This Study also found that lack of a coherent National Security Policy in Sri Lanka has been a key 
problem that needs to be addressed and corrected soon to ensure the safety and security of the country.

Keywords: 5Rs, Military, Nation State, Peace Building, Security, Sri Lanka

\section{Introduction}

Sri Lanka is an island nation that is situated off the southern tip of India. Geographically, this country is surrounded by the Indian Ocean, and separated from India by the Gulf of Mannar and Palk Strait (Global Edge, 2020). The country is home to many ethnic groups, mainly the Sinhalese, Tamils, and Muslims who live in different parts of the country. Sinhalese are settled on the southern, western and central part of the country, while Jaffna Tamils who mainly occupy the northern parts of the country are considered to be descendants of Indian tribes who arrived in the island over 1500 years ago (Upali, 2017, p. 01). Indian Tamils are the plantation workers brought to the island by the British tea planters during the 19th and 20th centuries (Migration profile, 2013, p. 02). "Sri Lanka is considered as a country with a multicultural, plural society wherein all groups live with mutual respect with regard to differing ethnicities and cultural heritages" (Upali, 2017, p. 02). According to the World Bank, Sri Lanka is presently categorized as a lowermiddle-income country with GDP per capita of $\$ 3,852$ (2019) and a total population of 21.8 million.

Sri Lanka is today considered as one of the most peaceful and secure countries in South Asia. This harmony was achieved after eliminating by military means a most powerful and brutal terrorist group, namely the LTTE. This was one of the most serious and protracted conflicts in the world in recent times, lasting 26 years (Lindberg \& Orjuela, 2011, p. 201). Hence, this war was ended but without reaching an agreement regarding the national problem that gave rise to it. Finally, the government became the supreme victor in this war in 2009 (Kilavuz, 2017, p. 8). However, it is important to consider the root causes that gave rise to this protracted conflict.

Sri Lanka was able to get independence from the British Empire in 1948. Independence led to further disagreements among the different ethnic groups. Several legislations passed by parliament created a lack of unity that led to calls for separation by the Tamils. The British "divide and rule" policy was used tactically, being based primarily on factors such as religion and ethnicity, to discourage unity among the different communities to prevent a unified national uprising. "Ethnicity was considerably politicized during the British period" (Lindberg \& Orjuela, 2011, p. 211). In 1956 Sinhala was made the sole official language, supplanting English. Tamil was not given a rightful place. In 1972 there was another turning point when Buddhism was officially given the foremost place in the new Constitution. "Civil disobedience 
campaigns conducted by the Tamils gradually transformed into rebellious acts of militancy against the state" (Orjuela, 2010, p. 15). As a response to the periodic acts of communal violence, northern people began to demand a separate state of their own on their traditional lands and further, they believed that a military approach was the only solution to resolve the issue. "The root causes of the conflict originated as a result of the failure of the state to deal with minority aspirations" (Orjuela, 2010, p. 15).

"The military is an institution established by the state for the purpose of defending the country from external threats and internal conflicts" (Geneva Centre for the Democratic Control of Armed Forces). The military's main role is to maintain national security. This includes guarding against threats from both within and without and ensuring the safety of the people, which are the key duties of the military (Ministry of Defence, Sri Lanka). The Sri Lankan military intervened on many occasions to maintain peace and security in the country when acts of terrorism were committed. "The Sri Lankan military forces crushed the deadliest military group and used all their hard power to defeat the LTTE" (Karunarathne, 2014, P. 99).

After the Sri Lankan civil war ended many social and economic problems arose, which continue to prevail. These problems must be seriously addressed by policymakers. After the elimination of terrorism (LTTE) in Sri Lanka, ordinary people had the opportunity to enjoy peace and security. A realistic school of thought argues that national security in any country is seen as the most important requirement for preserving peace. If the state is secure then those who live within it are secure (Bajpai, 2002, p. 45). Traditionally, the military is a special institution that has played an indispensable role in maintaining national security.

Despite all that, the role of the military has been much debated in the post-war scenario. Following the end of World War II, the concept of national security underwent significant changes. In this case, the role of the military and its relevance to the maintenance of security in Sri Lanka can be analyzed by using diverse approaches as well. Given the importance and the sensitivity of the issue, this paper highlights how attention is paid to the role played by the military and how they become involved in national problems while engaged in the maintenance of national unity/security. For instance, when the ethnic tensions heightened, the Sri Lankan government had to provide adequate security to particular areas by way of counter insurgency measures. After independence, successive governments have applied various strategies such as deploying intelligence services and introducing modern warfare techniques to maintain national security in Sri Lanka.

National security has been challenged on multiple occasions due to violent actions based on extremist ideologies being perpetrated in postindependence Sri Lanka. Each and every time, the military confronted these 
problems head on and brought positive outcomes to the nation. In fact, the role of the military has proved significant and crucial after the end of the civil war in 2009. In this context, military support was enlisted by the successive governments to rebuild both the northern and eastern provinces. The military has been actively engaged in the nation building process in fields such as reconstruction, resettlement, rehabilitation, reintegration and reconciliation as these are considered collectively as primary duties that will contribute to strengthening national security. During this long-term process, the military has proved itself as one of the state's leading institutions working to ensure national stability in Sri Lanka.

The implications of big power rivalries and emerging multidimensional challenges relating to national security in the post-Cold War era have widened and broadened the scope of national security. In our case, the emergence of the LTTE and the unsuccessful mediation resulted in chaos in the Island even long after Independence. "Failed peace talks and the collapse of the ceasefire agreement signed in 2002 saw the continuation of isolated battles, resulting in heavy casualties on both sides" (Upali, 2017, p. 14). There had been two different arguments in society regarding the ethnic issue. On the one hand, foreign countries believed that ethnic issues can be settled by negotiation; yet, national leaders believed that the military approach was necessary to bring peace. In this sense, military engagement must be understood in the context of two contentious perceptions regarding it both in Sri Lanka and abroad.

State security does not have a universally accepted definition. Scholars like Barry Buzan claim that national security is an important and sensitive issue that is directly related to protecting the national unity, territorial integrity and sovereignty of the nation-state (Buzan, 1991, p. 35). National security takes a prime position in the list of priorities of most nation-states. Essentially, Security is understood as follows - "In a world of self-help, all states are under at least potential threat from all other states, and as such each state must possess the capacity for self-defense" (Heywood, 2011, p. 45). According to Nabilo, national security can be defined as an intricate interaction between political, economic, military, ideological, legal, social and other internal and external factors through which individual states attempt to ensure acceptable provisions to maintain their sovereignty, territorial integrity, political independence, physical survival of their population, and possibilities for a balanced and rapid social development on an equal footing (Grizold, 1994, p. 40). Thus, national security can in more general terms be defined as the state of security of a nation-state (Bhandari \& Sharma, 2020, p. 21). It involves security of the country's territory, protection of the lives and property of its population, existence and maintenance of national sovereignty, and exercise of the basic functions of its society, such as economic, social, political, 
cultural, ecological, etc. (UNDP, 1994). Therefore, national security has become immensely important to the national interest of all countries, whether big or small.

In the case of Sri Lanka, security concern is a little bit different from the global norm. Rajapakshe (2013) noted that "national security is entirely dependent on the achievement of national cohesion, elimination of terrorism and formulation of effective responses against external attacks" (Rajapakshe, 2013, p. 145). Some authors have arguably stated that national security is the psychological freedom from fear whether coming from inside or outside (Kegley \& Wittkope, 2006, p. 449). Security concept was further challenged by the development of a new world order. In the name of national security, "all things can be threatened, all risks can be taken, and all sacrifices can be demanded" (Spiegel \& Williams, 2004, p. 123). The idea of national security was defined in terms of the state and military-centric approach rather than from the people's perspective, so it acquired a heavy military emphasis and character in the past. From a realistic standpoint, Heywood stated that national security is primarily based on responsibility for military power and that its capacity is critical for security.

Therefore, the military must be strong enough to deal with threats of any kind (Heywood, 2011, p. 322). Recently, the national security apparatus has paid attention to human security as well, and recognized that it must be protected through anti-terrorism laws, higher taxation and conscription (Chandra \& Bhonsle, 2015). The Human Development Report of 1994 prepared by Mahbub Ul Haq urged that the definition of security should be changed from being state-centric to human-centric (The Human Development Report [UNDP], 1994). Furthermore, it proposes that, "economic security, food security, health security, environmental security, personal security, community security and political security" should be the aim of a humanistic national security.

\section{Literature Review}

Several research studies have been conducted before this on the role of the military in post-war Sri Lanka. Although many of these studies focused on national security very few have focused on human security and on how the military can assist to promote human security in Sri Lanka. The main purpose of a Literature Review is to identify a research gap, formulate a theoretical framework and understand the concepts related to the research. The term "military role" is defined by many scholars and institutions.

Williams, P. (2008) presented several ideas as to what constitutes national security and its basic principles. This author considered theories on national security including realism, liberalism, game theory and constructivism. Further, this study paid attention to very important current 
issues such as peace studies, war, terrorism, genocide and mass killings, ethnic conflict, human security, alliances, regional institutions, contemporary challenges, the international arms trade, counter-terrorism, counterinsurgency, peace operations, private security, transnational organized crime, and energy security.

Heywood, A. (2011) presented his thoughts on National Security and its theoretical basis with practical perspectives. He has paid much attention to the current situation regarding military approaches, especially the military involvement of the USA and NATO in areas where they have conducted operations. Furthermore, this study deals with happenings relating to war and peace, human rights, humanitarian intervention, terrorism and about many other matters in global politics. This study provides several examples of military approaches to national security and human security at different levels.

A study by Soltani, F. and Yusoff, M. (2012) investigated extensively the approaches adopted by countries on national security and the theoretical basis of the national security concept. Thus, this study explains the main approaches of rationalism, relativism, and constructivism on the concept of security. In this study, researchers have paid considerable attention to comparative studies on national security concepts. Thus, this article's clarified rationalism is based on positivism, which argues that social and political phenomena can be explained in the same way that scientists explain the natural world.

Höglund, K. and Orjuela, K. (2010). This study was based on examining the practical difficulties involved in working towards conflict prevention. This study also focuses on international influences brought to bear on the domestic affairs of other countries. It discusses conflict prevention measures such as demilitarization, political power-sharing, justice and reconciliation, post-war reconstruction, economic development, etc. In Sri Lanka, though the conflict was over after three decades of bloodshed, the country is still unable to completely ensure human security by adopting the military approach. This study can assist scholars to understand the situation prevailing in Sri Lanka during war time and after it was brought to an end.

Karunarathne, A. (2014). This study focused on the role of the military in the post-war period by discussing how the military can be deployed to stimulate development in Sri Lanka. The study further touched on areas such as rehabilitation, reconciliation and nation-building concepts. There is a discussion of how the Sri Lankan armed forces functioned and how they were able to defeat the LTTE by military means.

Goldstein, J.S. (2003) explained the peace building processes that followed military intervention in many trouble spots around the world. That study provides a description of several international conflicts. The author has emphasized that "Conflict between states is not an unusual condition but a 
common one" (Goldstein, 2003, p. 183). This included a description of conflict classification. Further, this study showed that "states are increasingly using military muscle for purposes other than fighting." This book gives some instances of military involvement in humanitarian assistance after disasters, busting drug trafficking, and peacekeeping operations. Thus, this study makes it easier to understand the role of the military and national security on the global stage.

Webeland, C. and Galtung, J. (Ed) (2007). This work provides a basic introduction to conflict and peace studies. Also, the reconciliation process is explained analytically. The authors have given practical examples of reconciliation and peace building around the world. This study will prove highly relevant to those who wish to study the role of the military in different countries with emphasis on national security and the peace building concept.

\section{Research Problem}

National security is presently treated as a major topic in every nation state in the world. Generally, national security depends to a great extent on the military strength of a particular country. Therefore, the military has an unwavering responsibility to guard against threats and ensure the safety and security of the country from internal or external attacks. In Sri Lanka, national security and the role of the military have become widely discussed topics after the end of the civil war in 2009. Therefore, this research focuses on why the military is involved in civil administration, human security and peace building activities after the end of the civil war.

\section{Research Objectives}

The core objective of this research is to explore the role of the military in the post-war period in maintaining national security and conducting peace building activities in Sri Lanka. To some extent, this study expects to propose a sustainable solution for national security-based issues in Sri Lanka.

\section{Methodology}

The research design used in this article is qualitative in nature. The study used secondary sources such as books, articles, journals, relevant reports and websites in the data collecting process. This research analyzed the government initiatives that were undertaken to bolster national security after studying the strategies employed by the Sri Lankan military to uphold national security in the post-war scenario. This research conducted case studies on the role of the military in maintaining national security and peace building. This study also conducted an in-depth analysis of the Sri Lankan security imperatives. Some examples of the military's work are highlighted to demonstrate the broad capabilities of the Sri Lankan military during and after 
the conflict. Further, this study will draw attention to some basic principles that are commonly applied in national security related matters. The nature of the data presented is descriptive.

\section{Results and Discussions}

The Military is most important to the defense of any country. The main purpose of the military establishment is to protect and ensure the safety of the state and its peoples. Heywood noted in his book entitled "Politics" that the armed forces are often only seen and are generally above politics - "they guarantee the security and integrity of the state" (Heywood, 2004, p. 379).

According to the Ministry of Defence of Sri Lanka, the key role of the military is to ensure national security; nevertheless, the military must be ready to face other challenges too, such as disasters (Rajapakshe, 2013, p. 140). Military has not only provided security but has also been involved in other activities, including UN peacekeeping, disaster management, relief distribution and rescue operations, etc. (Ministry of Defence Report, 2018, p. 01). At the global level, the military has been performing a credible role in resolving international disputes as well. The international community invests enormous resources in international peace operations. Multiple UN peace missions are regularly deployed with the aim of establishing, keeping, and building global peace (Ruffa, 2017, p. 395).

In the context of Sri Lanka, the military was actively involved in safeguarding national security after the emergence of the LTTE in the Northern and Eastern provinces, densely inhabited by Sri Lankan Tamils. Most of them may have concluded that violent ideology was the only way to achieve their objectives. As a result of this belief, violent activities escalated after the rapid rise of the LTTE organization and the state's military response followed by repression of the Tamils. This war between the state forces and LTTE is considered as a historical event in the context of serious threats to the state (Höglund \& Svensson, 2007, p. 20). As a representative case, which shows the state's attitude towards LTTE insurgency and the intensity of the hostility, "during ceasefires the LTTE committed crimes and endangered our national security by attacking economic targets in Sri Lanka" (Rajapakshe, 2013, p. 139).

After these critical setbacks, the military had to come forward to eradicate terrorism in Sri Lanka. Silva (2007) explained how the military in Sri Lanka had to be ready to respond to threats effectively during that time. This was the first time after getting independence that national security was threatened so gravely. When faced with this problematic situation the government had to be seriously concerned about national security (Silva, 2007, p. 14). According to Karunaratne, the Sri Lankan military had to use its 
hard power and soft power to eliminate terrorism and establish normalcy in Sri Lanka (Karunaratne, 2014, p. 96).

The long festering internal conflict had directly affected the economic and political stability of Sri Lanka over many years. But, this brutality came to a peak with the forced closure of the Maavilaru sluice gate in the Northern Province. This was the main act that provoked the full scale military response against the militants. Senaratne (2017) noted that, "This rebellion also continued to threaten the human security of all Sri Lankans, especially their food security. This threat led to the government launching its military operation, which concluded with the defeat of the terrorist group" (Senaratne, 2017 \& Rajapakse, 2013, p. 140). According to Höglund and Orjuela (2011), "winning the war prevented further conflict as the government imposed a victor's peace on the vanquished." In Sri Lanka, the government won the war after defeating the LTTE in May 2009. However, winning the peace has remained a much greater challenge (Höglund \& Orjuela, 2011, p. 20).

As a consequence of the civil war, a huge price was paid in the economic, psychological, social and cultural spheres. Nearly 80,000 civilians lost their lives during the final stage of the war, and approximately 6,261 military personnel were killed, while 29,551 were disabled (Karunaratne, 2014, p. 97; Rajapakse, 2013, p. 143). Though it is not possible to say how many people died as a result of the war, it is estimated by some that approximately 100,000 civilians were killed, most of whom were Tamils (Kilavuz, 2017, p. 712). Besides that, there were thousands of internally displaced people, migrants, victims, child soldiers, and former LTTE combatants, etc. who needed immediate attention. "In the immediate aftermath of the war, there were a number of issues that needed prompt attention. First was the problem of the nearly 300,000 internally displaced people who had been used as the LTTE's human shield during the last phases of the war (Rajapakse, 2013, p. 07), which shows the severity of the war during the end stages.

Military and Government faced a number of challenges during the post-war period. In order to respond to these challenges, the government effectively recognized the priority areas and collaborated with other stakeholders to address them. Further, it was recommended that the following major activities be undertaken first - 1) "Return/ resettlement of displaced people, 2) rehabilitation of LTTE combatants including child soldiers, and 3) rebuilding of ravaged physical and human assets (Kulatunga \& Lakshman, 2013, p. 37). All in all, the initiatives that were launched by the government (5Rs) through mobilization of the military can be discussed under several subheadings as mentioned below. 


\section{Reconstruction}

After the conflict was brought to an end, the military made contributions that can be seen in several areas. The reconstruction of warravaged areas was one of the key government initiatives that was taken with the support of the military. "The military has accumulated considerable social trust in the post-war scenario" (Karunaratne, 2014, p. 98) due to fact that the military, apart from battlefield operations, helped to rebuild devastated areas where heavy fighting had taken place.

It was estimated that the number of people who were displaced and became refugees was very high. "As the final stage of the war came to a close in Sri Lanka, the northern and eastern provinces recorded the highest number of migrants, some of whom went abroad" (Amnesty International, 2009). Figures have not been estimated accurately for the civil war, yet it is believed that around 80,000-100,000 Sri Lankan lives were lost, with at least half the victims being civilians. Another 1.6 million of them were displaced or ended up as refugees (Dickwella, Ihjas, \& Navarathnam, 2013, p. 01). According to the Ministry of Defence (2013), 294,000 people were pushed out of their homes because of the war, and the Government initiated a quick recovery project to assist those people (A program like Northern Spring and deyata kirula, aimed at the revival of national spring in the devastated areas of northern and eastern Sri Lanka).

The intervention made by the military after 2009 includes not only the development of infrastructure but also uplifting of the socio-economic status of citizens living in the north and east of Sri Lanka (Karunaratne, 2014, p. 103). In addition, the government had to address other issues like restoring the transportation network, power supply, telecommunication services and irrigation canals.

Nevertheless, the building of houses in towns and villages were major challenges the government faced, and in this undertaking the military alone constructed nearly 6000 houses (Rajapakse, 2014, p. 146). 43,000 houses were completed under the grants made by the Indian Government (Indian High Commission in Sri Lanka, 2018). The Military was also recently involved in rebuilding houses that were destroyed in a clash between two religious groups in Aluthgama and Beruwala areas (Karunaratne, 2014, p. 102).

\section{Resettlement}

Resettlement was another major challenge faced by the Sri Lankan government after the end of the civil war. Government had to confront huge damages not only of physical infrastructure but also human lives. After the war concluded, a lot of people had to find asylum either abroad or resettle in some other area. Resettling people in their former villages was another challenge faced by the Government, which then provided aid to those who 
lived in the temporary camps and encouraged them to join the economic mainstream.

Samarasinghe (2009) argued that despite substantial donor aid for reconstruction, the hoped for recovery of the post-war economy, especially in the north and east, will suffer a serious setback (Samarasinghe, 2009, p. 456). In this regard the government took several steps to revitalize the production sectors, including crop agriculture, livestock, fisheries and tourism in this region within a remarkably short period (Defence Ministry, 2012). After a few years, a boom in the tourist industry and foreign direct investment revived Sri Lanka's economy, which helped expedite the resettlement of people in the war affected areas. All these primary support measures were also implemented with the assistance of the military. Economic sectors like cultivation, marketing, business, and industry are presently thriving in the previously war-torn areas through assistance provided by the government (Rajapakse, 2014).

\section{Rehabilitation and Reintegration}

It was reported that during the final stage of the war, about a thousand LTTE cadres surrendered to the security forces. In this connection it is important to know about the government's plan in terms of rehabilitation. Rajapakse noted that "One of the most important issues concerning the nearly twelve thousand surrendered LTTE cadres and four thousand detained cadres is that the government took the bold step of trying to rehabilitate nearly all of them so they could become productive citizens in the future. The vast majority of them have already been reintegrated into society" (Rajapakse, 2013, p. 07).

Karunaratne (2014) observed that "the intervention made by the military after 2009 included not only development of infrastructure but also uplifting of the socio-economic status of those who were living in the north and east of Sri Lanka. It included community services such as rehabilitation and vocational training for ex-LTTE combatants" (Karunaratne, 2014, p. 100). The measures undertaken by the government in respect of rehabilitation were impressive in comparison with the post-war measures conducted in other parts of the world. In this process, special support was given by the United Nations to rehabilitate former child soldiers, as the data showed that 595 of them surrendered to the government (Rajapakse, 2013, p. 145). As part of the program the government conducted lessons on spiritual theory, psychological care and vocational training for those who were interested in rejoining their families. As a result of the assistance provided by the government, 169 trainees from among the child soldiers managed to qualify to enter the University (Karunaratne, 2014, p. 97). 
Likewise, other child combatants were given formal education with the support of the Ministry of Education. According to a source from the Ministry of Defence, formal education was given to 2000 students from primary level while 65 students were given advanced education, which included a six-month long vocational program. The child soldiers were allowed to rejoin their families within one year (Rajapakse, 2013, p. 142). During the rehabilitation period, the military and government helped children to obtain basic education and provided support to continue their education by donating equipment. They conducted seminars for school children and sponsored educational tours, provided special programs on leadership training, self-employment and entrepreneurship (Karunaratne, 2014, p. 98). For this whole process, the United Nations and several other UN based international organizations provided immense support so the children could resume a normal life. The United Nations on this occasion delivered its contribution to the people (Goodhand, 1999, p. 08). In addition to the local NGOs, a number of international NGOs began working in the East, including Save the Children Fund (SCF), Oxfam and the International Committee of the Red Cross (ICRC). Most of these organizations started working as relief agencies in the north and east, but later some like SCF and Oxfam have shifted increasingly to rehabilitation and development activities (Goodhand, 1999, p. 07). Reintegration programs were also carried out for the former combatants who fought for the LTTE. Since the end of the conflict, trained suicide bombers have been rehabilitated and released to rejoin their communities. By April 2014, 11,935 LTTE ex-combatants had been reintegrated into society this way (Karunaratne, 2014, p. 104).

\section{Reconciliation}

This is the final and significantly important role undertaken by the government and the military after the conflict. Every civil war, after its ending, poses a challenge on how to reunite the entire nation. Sri Lanka is no exception to this process and so it faces the same problem, which is difficult to solve. Successive governments have tried to play their role effectively by making every necessary effort to reunite the communities that have been at loggerheads with each other.

In this regard, the government first identified the key priority areas that must be examined to provide relief to the war-affected people, and implement suitable programs to normalize their livelihood. Secondly, the government has been attempting to continue with the post-war peace building initiatives. While engaged in this whole process, the government has gradually realized that peace is difficult to establish unless reconciliation is brought about between the different communities. Reconciliation can be thought of as the restoration of a state of peace to a relationship, in which the conflicting 
communities are at least not harming each other, and can be trusted not to do so in future either; this means revenge is forgone as an option (Galtung \& Webeland, 2007, p. 174). In short, reconciliation means coming back together despite bad old memories.

To bring about reconciliation after the end of the civil war, the government organized several programs with the help of the military. As the military was no longer engaged in the battleground the government redirected its energies towards the post-war needs. As such, the military was directed to turn its attention towards aspects like rehabilitation, reconciliation and nation building (Karunaratne, 2014, p. 103). However, the current reconciliation process has been criticized by some western countries, as it was not in line with their recommendations. "Western nations are in touch with the Sri Lankan peace process and have recommended to the government that international guidelines should be followed in the reconciliation process" (Samarasinghe, 2009, p. 438). Similarly, the government's handling of other matters, including human rights, devolution of power, constitutional amendments, political reform, land distribution, and civil administration have also been highly criticized by the European countries (Rajapakse, 2013, p. 139).

The Government established the Ministry of National Integration and Reconciliation under the direct guidance of the President. This Ministry has made great contributions to the nation building process. As a responsible Ministry it has implemented numerous programs including the Integration Friendly Schools program, Integration and Reconciliation Friendly Sunday Religious Schools Program, Integration Friendly Media Program (Peace Journalism), Reconciliation Focused Youth Program, and Reconciliation Focused Economic Empowerment Program (Ministry of National Integration and Reconciliation, Performance Report, 2017, p. 06). Furthermore, in a move to promote reconciliation, the government launched programs to strengthen the economy, political plurality and social integrity projects in the north and east to provide relief and create a favorable environment for the war-affected people. Even after the termination of terrorism, the significance of the military has not been reduced yet. For instance, the military's peacetime roles during events such as a national calamity, natural disasters or any other securityrelated issues have justified the rationale for maintaining a national army. Therefore, it must be fully understood that the military not only secures the country in times of danger but also contributes towards the nation building process during peacetime.

\section{Conclusion}

National security is more widely discussed by the global community at present than ever before with the emergence of newly arising conflicts and 
global terrorism. Syria, Libya, Iraq and Yemen are some of the current battlegrounds in the world. Due to the emerging unexpected threats to national security, almost all countries are attempting to strengthen their national security by means of sophisticated weapons and highly trained armies. Sri Lanka is one such country where terrorism was militarily eliminated in 2009. Therefore, the majority of Sri Lankans acknowledge that the military played a key role in making Sri Lanka free from all forms of violence. After the end of the conflict and elimination of the LTTE, the government had to face many challenges in building a sustainable peace and achieving reconciliation. To address those challenges several primary initiatives have been carried out with the full support of the military.

In this regard, it is important to analyze the overall duty performed by military personnel apart from their conventional role. Military is currently engaged in many roles they have to perform for the country. Under the guidance of the military, the areas where fighting had taken place are now being transformed into peaceful settlements for the people, and those who worked with the LTTE have now been rehabilitated. Rajapakse (2013) said that during the keynote address he delivered at an event organized by the Sri Lanka Institute of Fundamental Studies and held at the Sri Lanka Foundation Institute. He was speaking on the topic of national security and future challenges. Further, he said that more military support was needed to rebuild the war-affected areas. During the process of establishing peace and security, the military relied on a concept known as "one family"- which means trust, zero weapons, honesty and dedication.

On Easter Sunday in April 2019, several blasts occurred in some churches and hotels in Sri Lanka, and this again opened the discourse on national security and the role of the military in peacetime. Growing extremism throughout Sri Lanka may be a significant threat to national security. Even though the military has managed to overcome religious fundamentalism, there is still a grave threat to national security from the offshoots of global terrorism. To sum up, the role of the military is of vital importance to a country to protect the state and the people from internal and external threats.

\section{Acknowledgements}

This study could not have materialized without the immense contributions of many academics, including Mr. Renuka Priyantha, Dr. Sampath Rajapakshe and Mr. Priyantha Mudalige at the University of Kelaniya in Sri Lanka. I express my gratitude to all those who provided timely and valuable guidance to make this study possible. 


\section{References:}

1. Asia Report. (2006). Sri Lanka: The Failures of the Peace Process, International Crisis Group Working to Prevent Conflict Worldwide. Retrieved From Https://Www.Crisisgroup.Org/Asia/South-Asia/SriLanka/Sri-Lanka-Failure-Peace-Process.

2. Bajpai, K. (2002). Beyond comprehensive security: Human security. Comprehensive Security: Perspectives from India's Regions. New Delhi: New India Foundation.

3. BBC. (2019). Sri Lanka attacks: Who are National Thowheed Jamath? Retirived Online https://www.bbc.com/news/world-asia-48012694

4. Bhandari, C. \& Sharma, R. (2020). Discourse of civil military relations in Nepal. Unity Journal, Volume I, 21-32.

5. Chandra, S. \& Bhonsle, R. (2015). National Security: Concept, Measurement And Management, Retrieved From Https://Doi.Org/10.1080/09700161.2015.1047217 337-359.

6. De Silva, K.M. (1999). Sri Lanka: The Security Problems of A Small State, Defense and Peace Economics, Retrieved From Https://Doi.Org/10.1080/1043071990840493310:4, 361-381.

7. Defense Seminar. (2014). Gotabaya Rajapakse Keynote Address Https://Www.Youtube.Com/Watch?V=Qq5jabvczhg.

8. Dickwella, R., Ihjas, M.M., Navarathnam, S. (2013). "Human Rights State of Internally Displaced Persons in Sri Lanka: A Politico-Legal Perspective", International Journal of Arts and Commerce. Retrieved from https://ijac.org.uk/images/frontImages/ gallery/Vol._2_No._5/11.pdf 2: 96-108.

9. Dupont, A. \& Reckmeyer, J.W. (2012). Australia's National Security Priorities: Addressing Strategic Risk in A Globalized World. Retrieved From Https://Doi.Org/10.1080/10357718.2011.637316 34-51.

10. Fakhreddin., S., Mohammad., Y., (2012), Concept of Security in the Theoretical Approaches, Research Journal of International Studies, retrieved from 09/10/2020

ConceptofSecurityintheTheoreticalApproaches.pdf

11. Grizold, A. (1994). The Concept of National Security in the Contemporary World. Internaional Journal on Word Peace, 11(3), 37-53.

12. Goodhand, G. (1999). Sri Lanka: NGOS and Peace-Building in Complex Political Emergencies. Retrieved from Third World Quarterly, Https://Doi.Org/10.1080/0143659991392920:1, 69-87.

13. Heywood, A. (2011). Global Politics. Palgrave, Macmillan

14. Heywood, A. (2004) Politics. Palgrave, Macmillan. 
15. Hoglund, K. \& Orjuela, C. (2011). Winning the Peace: Conflict Prevention after A Victor's Peace In Sri Lanka, Contemporary Social Science. P.( 19-37.)

16. Hoglund, K. \& Svensson, I. (2007). The Peace Process in Sri Lanka, Civil Wars, Retrieved From

Https://Doi.Org/10.1080/13698240208402519 5:4, 103-118.

17. Karunaratne, A. (2014). The Role of Military as an Instrument of Soft Power in Post-War Sri Lanka. SAARC Cultural Centre, Colombo, Sri Lanka Social Affairs. Vol.1 No.1, 95-109.

18. Kegley, J. R., Wittkope, R. E. Charles, W., (2006). World Politics (Trends \&Transformation), Clark Baxter Publishers: USA, Chapter 12, P. 449-531.

19. Kilavuz, I .T. (2017). Success or Failure In The Peace Process Of Ache And Sri Lanka:A Comparative Study, Terrorism And Political Violence. Retrieved from https://doi.org/10.1080/09546553.2017.1282860

20. Kulatunga, S.T.K, \& Lakshman, R.W.D. (2013). Responding to Security Threats: Livelihoods Under Protracted Conflict in Sri Lanka, Disasters, 2013, Oxford:John Wiley \& Sons Ltd.

21. Linberg, J \& Orguela, C. (2011). Corruption and Conflict: Connections and Consequences in War-Tone Sri Lanka. Retrieved From Https://Doi.Org/10.1080/14678802.2011.572455 205-233.

22. Migration profile Sri Lanka, Colombo: Institute of Policy Studies of Sri Lanka, 2013.

23. Ministry-Of-Defense. (2017). Performance Report, Retrieved From Https://Www.Parliament.Lk/Uploads/Documents/Paperspresented/Pe rformance-Report-Ministry-Of-Defence-2017.Pdf

24. Ministry of Defense and Urban Development, Sri Lanka. (2012). Performance Report. Retrieved from

https://parliament.lk/uploads/documents/paperspresented/performanc e_report_ministry_of_defence_and_urban_development_2012.pdf

25. Ministry of National Integration and Reconciliation Performance Report. (2017). Retrieved from http://nirmin.gov.lk/web/images/annual-reports/Performace-report-2017-PDF.pdf

26. Navari, C., \& Williams, (ed.) Security Studies: An Introduction, 2008, pp. 29-43.

27. Performance Report Ministry of Defense and Urban Development. Performance Report (2013). Retrieved from https://parliament.lk/uploads/documents/paperspresented/performanc e_report_ministry_of_defence_urban_development_2013.pdf 
28. Performance-Report-Ministry-of-Defense-Urban-Development. (2014).Retrieved from

https://www.parliament.lk/uploads/documents/paperspresented/perfor mance-report-ministry-of-defence-urban-development-2014.pdf

29. Rajapakse, G. (2014a). Keynote Address at Kotalawala Defense University. Retrieved from https://www.youtube.com/watch?v=CPAJgGaOXM8.

30. Rajapakse. G. (2013). Keynote Speech on National Security and Future Challe ngos in Sri Lanka, Retrived from Https://Www.Onlanka.Com/News/Defence-Seminar-2013-SecretaryDefence-Mr-Gotabaya-Rajapaksas-Vision-For-Sri-Lanka.Html

31. Rajapakse, G. (2014). Sri Lanka's National Security, Retrieved on $24^{\text {st }}$ of January in 2019 from

content/uploads/2014/08/Sir_Lankas_National_Security_corrected.pd $\mathrm{f}$ http://www.sinhalanet.net/wp

32. Ruffa, C. (2017). Military Cultures and Force Employment in Peace Operations, Security Studies. Retrieved from Https://Doi.Org/10.1080/09636412.2017.1306393 26:3, 391-422.

33. Rukshan, D.G.R.N. (2019). The Role of Military in Peace Building and Reconciliation Post War in Sri Lanka, 12 $2^{\text {th }}$ Annual Research Conference, Colombo, Royal Asiatic Society.

34. Senaratne, B. (2017). National Security of Sri Lanka: Importance of Mass Media And Communication. International Journal Of Multidisciplinary Studies (IJMS) Volume 4, Issue 2, 2017 DOI: Http://Doi.Org/10.4038/Ijms.V4i2.23.

35. Spielel, L. S., Taw, M. J., Williams, P.K, (2004). World Politics in a New Era, Clark Baxter Publishers, USA.

36. Samarasinghe, S. W. R. De A. (2009). Sri Lanka: The Challenge of Postwar Peace Building, State Building, And Nation Building, Nationalism and Ethnic Politics, DOI: 10.1080/13537110903393462 Https://Doi.Org/10.1080/1353711090339346215:3-4, 436-461.

37. The Human Development Report. (1994). The United Nations, New York.

38. Upali, P. (2015). The Post- Conflict Rebuilding Process Of Sri Lanka: A Content Analysis Of Issues, Challenges And Lessons Learnt. Retrieved From

Https://Www.Researchgate.Net/Publication/303792101.

39. Upreti. B. R, Rajan. B.G, Wagle. S, (2013), Human Security in Nepal: Concepts, Issues and Challenges, Kathmandu, Nepal Institute for Policy Studies and South Asia Regional Coordination Office of NCCR (North-South) 
40. Webel, C. \& Galtung, J. (Ed) (2007). Handbook of Peace and Conflict Studies, Abingdon, Oxon, Rutledge.

41. Weber, C, (2010). International Relations Theory: A Critical Introduction, 3. ed., London: Routledge,

42. Williams, Paul D. ed. (2008). Security Studies: An Introduction, Routledge, UK.

43. World bank, (2020), Annual Report of country Profile, retrived from https://www.worldbank.org/en/country/srilanka/overview 